\title{
Murottal Therapy To Anxiety Levels Of Patients Pre-Operative At Sari Mulia Hospital Banjarmasin
}

\author{
R. Topan Aditya Rahman ${ }^{1 *}$ \\ 1*Academy of Midwifery Sari Mulia Banjarmsin Indonesia \\ r_topan_aditya@akbidsarimulia.ac.id \\ , Mohdari ${ }^{2}$ \\ ${ }^{1}$ School of Economical Science Nasional Banjarmasin Indonesia \\ Mohdari@gmail.com
}

Aditya Prasetyo ${ }^{3}$

${ }^{2}$ School of Health Science Sari Mulia, Banjarmasin Indonesia

aditya_prasetyo@gmail.com

\begin{abstract}
Objective: This is to analyze the effect of murottal therapy to anxiety levels of patient preoperative in the Installation Central Surgical (ICS) General Hospital Sari Mulia Banjarmasin.

Methods: This research uses quantitative research Quasi-experimental design with the one-group pretest-posttest design. The sampling technique used purposive sampling with a sample size of 22 patients pre-operation. Collecting data was using questionnaires. The data were analyzed using Wilcoxon test statistic

Results: There is a significant association between murottal therapy to anxiety levels of patients preoperative in the Installation Central Surgical (ICS) General Hospital Sari Mulia Banjarmasin.

Conclusion: Murottal therapy is an important thing to do when someone gets ill or will have the surgery. Murottal therapy can decrease or release the anxiety levels in patients.
\end{abstract}

Keywords: Anxiety Levels, Installation Central Surgical, Murottal, Patient, Preoperative.

\section{INTRODUCTION}

Surgery or surgery is a difficult experience. Some bad possibilities may occur, such as exaggerated responses to anxiety experienced by families and patients. The anxiety experienced is usually associated with a foreign threat, a threat to life safety in connection with the surgery. Nurses have an important role in every surgery, both before and after surgery [1]. Surgery on its execution may cause anxiety, which is associated with pain, disability, and can also lead to death [2].

Before surgery there is often an anxiety problem that is a patient's emotional reaction. This is in response to patient anticipation of an experience that is perceived as a threat to the role in the patient's life, body integrity and even life [3].

When anxiety does not get an accurate treatment, it is possible that this adds to the anxiety of patients undergoing surgery and 
will lead to incompetence and understanding of events during treatment and surgical procedures, as well as disrupt the healing and recovery process. Therefore, communication is indispensable in nursing actions to reduce anxiety levels of patients [4].

Many nursing actions to deal with anxiety, pain, one music therapy that can reduce the level of anxiety in patients. In addition to music therapy rebates Murottal Al-Qur'an can also reduce anxiety. Murottal is a recording of Quranic letters cast by a Qori '. Surat Al-Qur'an is like a sound wave that has a certain strength and wave, spread in the body and then become a vibration that can affect the function of the motion of cells that inside the brain and make inner comfort in the smooth. The cells affected by the recitation of the Qur'an will make the neurons stable again. The Qur'an has several benefits because it contains some aspects that can affect the health, among others: contains elements of meditation, autosuggestion, and relaxation [5].

Introduction conducted by researchers at Sari Mulia Banjarmasin General Hospital on November 25 to December 1, 2016 by observation and discussion of 12 patients who will undergo surgery obtained varying data, 6 patients (50\%) are categorized as anxious, the patient stated that he was worried and afraid, for fear that if the surgery was first experienced a failure, the patient also stated that the night is restless and difficult to sleep due to bad thinking afraid of things that are not desired, while 4 patients $(33.33 \%)$ in categorize anxious medium and lightweight because previously had undergone SC surgery, the patient stated that he was afraid to even restless that the patient still can rest for sleep and 2 patients (16.66\%) stated not too worried because patients are grateful his illness can heal and every night patient read pray.

Based on the above background, conducted research on murrotal therapy to pre-operative patient's anxiety level in the center of central surgery at Sari Mulia General Hospital Banjarmasin.

\section{METHODS}

This research is a quantitative research with Quasi-Experimental, with pretest-posttest one group design. The population of pre-operative patients in December 2016, which amounted to 218 patients and a sample of preoperative patients taken according to the sample formula according to [6], obtained a total of 22 samples, so that the samples were accurately numbered 22 people who will undergo surgery with the technique of taking Purposive Sampling sample. The data were collected using a questionnaire published by Hamilton Ratting Scale For Anxiety (HRS-A) [7].

The methods are as presented below:

a. Univariate Analysis

Univariate analysis was performed on each variable from the research result to know the 
distribution, frequency, and percentage of each variable studied.

\section{b. Bivariate Analysis}

This analysis is conducted on two variables that are suspected to be related (testing the hypothesis) i.e. knowing the relationship of independent variables with dependent variable through Wilcoxon test.

\section{RESULTS}

Table 1. Distribution of respondents' characteristics based on the gender of the pre-operation

\begin{tabular}{cccc}
\multicolumn{4}{c}{ based on the gender of the pre-operation } \\
\hline No. & Genders & Frequency & $\%$ \\
\hline 1. & Males & 15 & $68,2 \%$ \\
2. & Females & 7 & $31,8 \%$ \\
\hline & Total & 22 & $100 \%$
\end{tabular}

Table 1 shows that of 22 respondents, the highest number of male patients was 15 respondents $(68.2 \%)$, and the least were women $(7,8 \%)$.

Table 2 Distribution of Respondents Based on the Ages of preoperation

\begin{tabular}{cccc}
\hline No. & Ages & Frequency & $\%$ \\
\hline 1. & $18-30$ years & 9 & $40,9 \%$ \\
2. & $31-42$ years & 10 & $45,5 \%$ \\
3. & $43-55$ years & 3 & $13,6 \%$ \\
\hline & Total & 22 & $100 \%$ \\
\hline
\end{tabular}

Table 2 states that of the 22 respondents, the highest number of patients were 31-42 years old, 10 respondents (45.5\%), and the lowest patient rating was 43-55 years old, 3 respondents $(13.6 \%)$.

Table 3 Distribution of Respondents Based on Operation Type

\begin{tabular}{cccc}
\hline No & $\begin{array}{c}\text { Operation } \\
\text { Types }\end{array}$ & Frequency & \% \\
\hline $\mathbf{1}$ & General & 12 & 54,5 \\
\hline $\mathbf{2}$ & Obgyn & 2 & 9,1 \\
\hline $\mathbf{3}$ & Oncology & 4 & 18,2 \\
\hline $\mathbf{4}$ & Urology & 4 & 18,2 \\
\hline & Total & 22 & 100
\end{tabular}

Table 3 states that of the 22 respondents, the highest number of patient appraisers were the general operations of 12 respondents $(54.5 \%)$, and the lowest patient appraisers were obgyn surgery i.e. 2 respondents $(9.1 \%)$.

Table 4 Frequency Distribution of Level of Anxiety Before the Murottal Therapy

\begin{tabular}{llcc}
\hline No. & Categories & Frequency & $\%$ \\
\hline 1. & Severe anxiety & 0 & $0 \%$ \\
2. & Highly anxiety & 14 & $63,6 \%$ \\
3. & Mediocre anxiety & 6 & $27,3 \%$ \\
4. & Mild anxiety & 2 & $9,1 \%$ \\
5. & No anxiety & 0 & 0 \\
\hline Total & & 22 & $100 \%$
\end{tabular}

Based on table 4 on the characteristics of respondents based on anxiety level prior to murottal therapy, the most anxiety level is severe anxiety which amounted to 14 respondents $(63.3 \%)$, moderate anxiety ie 6 respondents $(27.3 \%)$, and not anxious ie 2 respondents $(9.1 \%)$.

Table 5 Frequency Distribution of Level of Anxiety After the Therapy

\begin{tabular}{cccc}
\hline No & Operation Types & Frequency & \% \\
\hline $\mathbf{1}$ & Severe anxiety & 0 & 0 \\
\hline $\mathbf{2}$ & Highly anxiety & 1 & 4,5 \\
\hline $\mathbf{3}$ & Moderate anxiety & 14 & 63,6 \\
\hline $\mathbf{4}$ & Mild anxiety & 5 & 22,7 \\
\hline $\mathbf{5}$ & No anxiety & 2 & 9,1 \\
\hline & Total & 22 & 100 \\
\hline
\end{tabular}

From table 5 on the characteristics of respondents based on the level of anxiety after the murottal therapy, the level of highly anxiety that is 1 respondent $(4.5 \%)$, moderate anxiety that is 14 respondents $(63.6 \%)$, mild anxiety that is 5 respondents $(22,7 \%)$, and not anxious i.e. 2 respondents $(9.1 \%)$. 
Table 6 Analysis of the Influence of Murottal Therapy on the Level of Anxiety

\begin{tabular}{cccc}
\hline No & Level of Anxiety & $\begin{array}{c}\text { Before the } \\
\text { therapy }\end{array}$ & $\begin{array}{c}\text { After the } \\
\text { Therapy }\end{array}$ \\
\hline $\mathbf{1}$ & Severe & $0(0 \%)$ & $0(0 \%)$ \\
\hline $\mathbf{2}$ & Highly & $14(63,6)$ & $1(4,5)$ \\
\hline $\mathbf{3}$ & Moderate & $6(27,3)$ & $14(63,6)$ \\
\hline $\mathbf{4}$ & Mild & $2(9,1)$ & $5(22,7)$ \\
\hline $\mathbf{5}$ & No anxiety & $0(0 \%)$ & $2(9,1)$ \\
\hline \multirow{4}{*}{ Total } & $22(100)$ & $22(100)$ \\
\hline P Value & & 0,000 \\
& $\boldsymbol{\alpha}$ & & $\leq 0,05$
\end{tabular}

Based on table 6 , it was found that the anxiety level of respondents before and after murottal therapy is very significant. This is seen from the significant value of $\mathrm{P}$ value of 0,000 . This indicates that the value is smaller than the value of $\alpha$ is $\leq 0.05$ where in that case $p \leq \alpha$ then the hypothesis is accepted which means there is an influence between murottal therapy to the anxiety level of preoperative patients in the installation room of Central Surgery (IBS) General Hospital of Sari Mulia Banjarmasin.

\section{DISCUSSION}

\section{The level of anxiety of the patient before the murottal therapy.}

The anxiety level of pre-operative patients before the murottal therapy of $\mathrm{Al}$ Qur'a mostly on the level of severe anxiety can be seen in table 4.6 that is as many as 14 people or $63.6 \%$. This is caused by the fear of lung disease in patients who will undergo surgery, it is proved when the researchers give a questionnaire before murottal therapy $\mathrm{Al}$ -
Qur'an and the results of fill out the questionnaire most patients feel afraid and anxious when going through surgery. Most patients also experience severe anxiety due to undergoing surgery for the first time. This is consistent with the research conducted by Pailese, A., Cecconi, M., Moreale, R., \& Skrap, M. (2012) who stated that those who experience first-hand operations first on certain parts of the body will experience higher anxiety [8].

The experience of surgery is an experience that significantly affects the patient's pre-surgical matters. Anxiety greatly affects the field of perception and makes the patient unable to think about anything else. This is aligned in the opinion [7], suggesting that severe anxiety can be triggered by behavioral responses with excessive anxiety, worry, bad premonition, anxiety, even imagined in dreams. While the physiological response triggered the rise of the pulse, shortness of breath, even headache.

\section{The level of anxiety of the patient after the murottal therapy.}

Level of anxiety in pre-operation patients after the murottal therapy of Al-Qur'a mostly on the level of severe anxiety can be seen in table 4.7 ie severe anxiety that is 1 respondent $4.5 \%$, for respondents with moderate anxiety that is 14 respondents or $63,6 \%$ mild anxiety 5 or $22.7 \%$, and respondents experienced no anxiety ie 2 respondents, or $9.1 \%$. This happens because the provision of murrotal therapy Al-Qur'an 
effective to patients who will undergo surgery. The likelihood of this happening is due to the patient obtaining calm in the heart to face the surgery to be followed by the murottal therapy of Al-Qur'an.

The condition of the patients after being given the murottal therapy of the Qur'an seems calmer, the patient is more able to think positively, even after the murottal therapy of the Qur'an they say that the surgery action will be done solely for the cure of his illness.

This is evidenced by opinion (Kate and Mucci, 2002) cited from research (Faridisi, 2013) states that listening to murottal chants of the Qur'an can reduce anxiety, listening to murottal chants of the Qur'an can make the heart to be calm and calm [9, 10]. In line with the research conducted (Mustamir, 2009 in Mayrani \& Hartati, 2013) states that listening to murottal chants of the Qur'an with a slow tempo that along with the heartbeat that can stimulate the hypothalamus to release hormone endorphins, a hormone that can make people feel happy. The relaxation arising from the murottal chanting of the Qur'an gives rise to serenity and decreases anxiety [11].

\section{Effect of murottal therapy on the anxiety level of preoperative patients who will undergo surgery at IBS Sari Mulia Hospital Banjarmasin}

There was a significant change in preoperative patient anxiety level before and after Koranic murottal therapy from severe anxiety level of 14 respondents or $63.6 \%$ to
14 respondents with moderate anxiety level 14 respondents $63,6 \%$.

From the results of statistical tests using the test Wilcoxon sign rank test, obtained the value of $p$-value of $=0,000$ means $p$-value smaller than $\alpha$ or $p \leq 0.05$ then, in this case, stated that there is influence of murottal therapy before the pre-operative anxiety level in the room the central surgery installation of Sari Mulia Banjarmasin General Hospital. This is indicated by the decrease in anxiety of respondents who experienced severe anxiety initially amounted to 14 respondents or (63.6\%) to 1 respondent with severe anxiety or (4.5\%), while for moderate anxiety also experienced an increase that initially amounted to 6 respondents or (27.3\%) to 14 respondents or $(63.6 \%)$. As for the mild anxiety also experienced an increase that initially amounted to 2 respondents or $(9.1 \%)$ to 5 respondents or $(22.7 \%)$, and respondents with no anxiety experienced an initial increase in 0 respondents or $(0 \%)$ to 2 respondents or $(9.1 \%)$. In this study, on all respondents conducted murottal therapy AlQur'an that can be seen in table 4.8 that is as much as 22 respondents or $100 \%$ of the number of respondents. The respondents who did not experience anxiety reduction were 1 respondent with severe anxiety this happened because of experience undergoing surgery for the first time, that those who experience first experience surgery especially on the certain body part, will experience anxiety even higher depression. At a young age of approximately 
22 years is also a factor of anxiety does not decrease, the fear of excessive loss of life makes someone more afraid to undergo surgery, in accordance with research Pailese, A., Cecconi, M., Moreale, R., \& Skrap, M. (2012). [8]

Murottal therapy Al-Qur'an is a relaxation therapy, where therapy is like a sound wave that has the power to make people who listen to it feel relaxed even calm after listening. The sense of calm can also arouse the confidence of someone who will undergo surgery, especially Muslims. In accordance with research (As Syuyuti, 2006 in Siswantinah, 2011). [5] In addition to murottal therapy the Qur'an music therapy can also decrease anxiety, can even speed up healing. Music therapy can also be used not only Muslims, but all religious people can also use music therapy as one of the therapy lowering anxiety. In this therapy music is a facilitator to make a person's state become relaxed and comfortable so that the work of the parasympathetic nervous system will work more dominant [12].

According to Arwani's research, Iis Sriningsih (2013) says that the influence of aromatherapy positively impacts the decrease in anxiety levels, [13] the same is pointed out by Savitri Wenny and Nani Fidayanti, (2016), saying that music therapy also positively affects patients' who will undergo surgery, this is due to aromatherapy and music therapy gave directly [14]. Similarly, the provision of murottal therapy of the Qur'an given directly can also decrease the anxiety level of this thing because someone who listens to lmurottal can increase the concentration and feel comfortable and calm so as to facilitate someone to regulate the breathing so that will increase the level of $\mathrm{O} 2$ in the blood so that the metabolism in the body becomes stable and anxiety decreases [15].

Limitations in this study are primary data and second secondary data support, this study is also not maximized because the respondents who ate the average operation did not fit the limits of specific inclusion characteristics. In this study also, unfortunately, did not use the control group so can not compare between the given therapy and not given therapy, in this study did not discuss the more specific age factors about anxiety, only in general and overall course. So it can be concluded that there is a significant influence between murottal therapy on preoperative patient anxiety level in the installation room of Central Surgery (IBS) Sari Mulia General Hospital Banjarmasin. With $P$ value of $0,000 \leq 0,05$.

\section{CONCLUSION}

There is influence murottal therapy prior to the anxiety level of preoperative patients in the central surgery installation Sari Mulia Banjarmasin General Hospital. 


\section{REFERENCES}

[1]. Rondhianto. Perawatan Post Anestesi di Ruang Pemulihan (RecoveryRoom). http://Keperawatan-perioperatif.htm. Di akses tanggal 16 November 2016.

[2]. Potter, P,A dan Perry, A,G. Buku ajar fundamental keperawatan. 2005. vol.2 Edisi 4. Jakarta EGC.

[3]. Brunner \& Suddarth. Keperawatan medikal bedah, 2002. Edisi 8 Vol 1 dan 3. Jakarta : EGC.

[4]. Setyaningsih Tri Rini, Meirina SS. Perbedaan Tingkat Kecemasan Pre Dan Post Operasi Di Bangsal Bedah Kenanga Rsud Prof. Dr. Margono Soekarjo Periode 1-5 Oktober 2012. Mandala of Health. Volume 6, Nomor 1

[5]. As Syuyuti, J.A. (2006).1445-1505 M, Pengobatan Cara Nabi. Bandung.

[6].Sugiono. (2011). Statistika untuk penelitian. Bandung:Afabeta..

[7]. Hawari, Dadang. Managemen stress cemas dan depresi. Jakarta: Balai Penerbit fakultas Kedokteran Universitas Indonesia Jakarta. 2011.

[8]. Pailese, A., Cecconi, M., Moreale, R., \& Skrap, M. Pre-operative stress, anxiety, depression and coping strategies adopted by patients experiencing their first or recurrent brain neoplasm: An explorative study. 2012. Stress Health, 28 (5), 416-25.

[9]. Kate \& Mucci, R. The Healing Sound of Music. PT. Gramedia Pustaka. 2002.

[10]. Faradisi, Firman.2013. Efektivitas Terapi Murotal dan Terapi Musik Klasik terhadap Penurunan Tingkat Kecemasan Pasien Pra Operasi di Pekalongan. Jurnal Ilmiah Kesehatan. Vol V No. 2 September 2012 di akses tanggal 16 november 2016.

[11]. Mayrani, Eva Dwi dan Elis Hartati. Intervensi Terapi Audio Dengan Murottal Surah Ar-Rahman terha- dap Perilaku Autis. Jurnal Kepera- watan Soedirman. 2013.

[12]. Savitri Wenny, Nani Fidayanti. 2016. Terapi Musik Dan Tingkat Kecemasan Pasien Pre Operasi Bangsal Bedah Ruang Melati Panembahan Senopati Bantul Yogyakarta. [skripsi], Yogyakarta: Stikes Jenderal A. Yani Yogyakarta.

[13]. Arwani, Iis Sriningsih. Pengaruh Pemberian Aromaterapi Terhadap Tingkat Kecemasan Pasien Sebelum Operasi dengan Anestesi Spinal di RS Tugu Semarang. Jurnal Keperawatan Jiwa . 2013. Volume 1, No. 2: 129-134

[14]. Savitri, Wenny, dkk. Terapi Musik dan Tingkat Kecemasan Pasien Preoperasi.http://ejournal.stikesayaniyk.ac.id/i ndex.php/MIK/article/view/44. diakses tanggal 16 November 2016.

[15]. Nurfadillah, Edi Pengaruh Membaca Dzikir Asmaul Husnah Terhadap Kecemasna Pada Pasien Pre Operasi di RSU PKU Muhamadiah Bantul. [skripsi], Yogyakarta: Universitas Muhammadiyah Yogyakarta. 2014. 